\title{
Hubungan Pengetahuan dan Sikap Terhadap Kejadian Keputihan
}

\author{
Shabrina Yuamita Ilmassalma, Hartati Eko Wardani*, Anindya Hapsari \\ Universitas Negeri Malang, Jl. Semarang No. 5 Malang, Jawa Timur, Indonesia \\ *Penulis korespondensi, Surel: hartati.eko.fik@um.ac.id
}

Paper received: 31-9-2021; revised: 14-9-2021; accepted: 21-9-2021

\begin{abstract}
Vaginal discharge is a condition that is often experienced by women throughout their lives from adolescence to menopause. Often considered as a symptom or disorder in the reproductive organs. At the age of 15-24 years as many as 45 percent of 2.9 million Indonesian women experience vaginal discharge. This situation, it is necessary for every individual to realize how to handle it properly. The results of the preliminary study were 90 percent of respondents who experienced vaginal discharge. The purpose of this study was to determine how significant the relationship between knowledge and attitudes towards the incidence of vaginal discharge was in students of the Faculty of Sports Science Class of 2019 State University of Malang. The type of research used is quantitative correlation with cross sectional approach. The population in this study were 197 female students with 134 female students who were sampled using the proportional stratified random sampling technique. Data were analyzed using Spearman's test with the result that there was no significant relationship between knowledge and the incidence of vaginal discharge (p equals 0.520) and there was no significant relationship between attitudes and the incidence of vaginal discharge ( $\mathrm{p}$ equals 0.651 ).
\end{abstract}

Keywords: leucorrhoea; teenagers; knowledge; attitude

\begin{abstract}
Abstrak
Keputihan merupakan keadaan yang sering dialami wanita sepanjang hidupnya mulai dari remaja hingga menopause. Sering dianggap sebagai sebuah gejala maupun kelainan organ reproduksi. Pada usia 15-24 tahun sebanyak 45 persen dari 2,9 juta wanita Indonesia mengalami keputihan. Pada keadaan tersebut perlu adanya kesadaran setiap individu dengan cara melakukan penanganan dengan baik. Hasil studi pendahuluan terdapat 90 persen responden yang mengalami keputihan. Tujuan dari penelitian ini untuk mengetahui seberapa bermaknanya hubungan pengetahuan dan sikap terhadap kejadian keputihan pada Mahasiswi Fakultas Ilmu Keolahragaan Angkatan 2019 Universitas Negeri Malang. Penelitian yang digunakan ialah kuantitatif korelasional dengan pendekatan cross sectional. Populasi dalam penelitian ini sebanyak 197 mahasiswi dengan 134 mahasiswi yang dijadikan sampel dengan menggunakan teknik Proportionate stratified random sampling. Hasil analisis menggunakan uji Spearman ialah tidak ada hubungan yang bermakna pada dua variabel yang diteliti dengan kejadian keputihan (p sama dengan 0,520) dan (p sama dengan $0,651)$.
\end{abstract}

Kata kunci: keputihan; remaja; pengetahuan; sikap

\section{Pendahuluan}

Rentang usia dari World Health Organization (WHO) terbaru menyebutkan bahwa usia muda ada pada usia 10-14 tahun, usia remaja 15-19 tahun, dan dewasa muda 20-24 tahun. Perubahan paling mencolok yang dialami remaja adalah perubahan fisik saat pubertas. Berbagai perubahan yang dialami remaja dapat menimbulkan beberapa masalah kesehatan, khususnya masalah kesehatan reproduksi remaja. Masalah kesehatan remaja yang cukup sering terjadi adalah terjadinya keputihan (leukorrhea/fluor albus) pada remaja wanita. 
Masalah tersebut perlu adanya penanganan yang serius, mengingat banyaknya cara untuk mendapatkan informasi terkait hal tersebut (Ilmiwati \& Kuntoro, 2017).

Berdasarkan data, rata-rata lebih dari 50\% wanita di dunia dipastikan mengalami keputihan (Darma, 2017). Data statistik Kementerian Kesehatan Republik Indonesia tahun 2009 dalam Irmayanti (2016), menunjukkan setidaknya 45\% wanita berusia 15-24 tahun mengalami keputihan yang tergolong Wanita Usia Subur (WUS). Hasil penelitian ini menyebutkan bahwa wanita Indonesia berpotensi mengalami keputihan sebesar $90 \%$ (Irmayanti \& Lusiana, 2017). Di Indonesia, sebanyak 75\% wanita dan hampir 45\% wanita mengalami keputihan lebih dari satu kali (Sari, 2013).

Keputihan merupakan keadaan seorang wanita yang menjadi sebuah gejala adanya kelainan alat reproduksi, keputihan terbagi menjadi dua yaitu fisiologis (normal) dan patologis (tidak normal). Apabila keputihan disepelekan maka dapat menimbulkan dampak kesehatan yang lebih besar, antara lain penyakit Trichomonas atau trikomoniasis (Lazenby, 2013). Selain itu, dampak kesehatan lain akibat keputihan yang tidak tertangani dengan baik yaitu infertilitas (kemandulan), radang panggul, dan kanker serviks (Febryary, 2016). Berdasarkan penelitian yang dilakukan oleh Ahmad dkk (2011), didapatkan beberapa hal yang mempengaruhi terjadinya keputihan yaitu: pengetahuan, sikap (attitude), dan higiene perorangan (personal hygiene) (Irmayanti \& Lusiana, 2017). Keputihan yang terjadi karena infeksi ini pada umumnya disebabkan oleh kebiasaan menjaga kebersihan atau personal hygiene habits organ kewanitaan yang kurang baik. Selain itu, keputihan juga dapat terjadi karena keadaan geografis dimana Indonesia adalah salah satu negara yang tingkat kelembabannya cukup tinggi sehingga remaja akan berpeluang besar mengalami keputihan (Wati, 2017). Menurut Sari (2013), perilaku yang dapat mempengaruhi kejadian keputihan antara lain sikap, motivasi, informasi, dan peran orang tua tentang hygiene organ kewanitaan. Selain itu, aktivitas yang melelahkan dan berdampak pada kurangnya istirahat atau tidur akan memicu stress dan kemungkinan terjadinya keputihan akan meningkat (Abiyoga dkk, 2019). Pengetahuan yang dimiliki seseorang akan berpengaruh pada perilaku mencegah keputihan dan ini selaras dengan pernyataan dari Tanuwidjaya (2002) dalam Lusiana (2019) yaitu tingkat pengetahuan remaja berpengaruh terhadap kondisi kesehatan. Dari pernyataan tersebut maka dapat diketahui seberapa penting pengetahuan remaja untuk kesehatannya. Serta perilaku perawatan hygiene organ kewanitaan perorangan yang kurang baik akan menjadi penyebab terjadinya keputihan. Penyebab keputihan juga berkaitan dengan sikap individu yang tidak memperhatikan kebersihan organ reproduksinya (Nikmah \& Widyasih, 2018).

Pada rentang usia 15-24 tahun, sebagian remaja sedang mengenyam pendidikan di salah satu fakultas Perguruan Tinggi Malang, yang dimaksud ialah Fakultas Ilmu Keolahragaan (FIK). Terdapat empat jurusan pada Fakultas tersebut antara lain Pendidikan Jasmani Kesehatan dan Rekreasi (PJKR), Pendidikan Kepelatihan Olahraga (PKO), Ilmu Keolahragaan (IK) dan Ilmu Kesehatan Masyarakat (IKM). Kegiatan remaja putri yang selanjutnya disebut mahasiswi di FIK berbeda dengan mahasiswi di luar FIK. Mengingat perkuliahan yang dilakukan identik dengan jadwal yang padat dan terdiri dari kuliah teori dan praktik. Hal tersebut memungkinkan mahasiswi FIK memiliki waktu yang terbatas untuk merawat kebersihan diri. Berdasarkan paparan di atas, maka hal tersebut menjadikan peneliti memiliki ketertarikan untuk melakukan penelitian tentang berbagai faktor yang berhubungan dengan kejadian keputihan. Variabel yang diambil yaitu pengetahuan karena pengetahuan sangat berpengaruh serta 
sebagai dasar kebiasaan seseorang dan sikap karena dari penelitian sebelumnya banyak yang menyimpulkan bahwa variabel tersebut menjadi faktor terjadinya keputihan. Judul penelitian yang diangkat yaitu "Hubungan antara pengetahuan dan sikap terhadap kejadian keputihan pada mahasiswi Fakultas Ilmu Keolahragaan Angkatan 2019 Universitas Negeri Malang”.

\section{Metode}

Jenis penelitian ini adalah penelitian kuantitatif korelasional menggunakan pendekatan cross sectional yang digunakan untuk mempelajari sebuah korelasi antara beberapa faktor risiko dengan dampak dengan cara observasional atau pengumpulan data sekaligus di waktu yang sama (Notoatmodjo, 2012). Populasi yang ditentukan dilakukan perhitungan dengan menggunakan teknik Proportionate stratified random sampling dimana seluruh populasi diambil acak dengan menentukan jumlah sampel sesuai pengkategorian. Populasi dalam penelitian ini adalah Mahasiswi FIK Angkatan 2019 sejumlah 197 mahasiswi. Besar sampel ditentukan dengan rumus Yamane (Sugiyono, 2018) sehingga ditemukan jumlah sampel sebanyak 134 mahasiswi. Penelitian telah dilakukan kaji etik dengan Komisi Etik Penelitian Kesehatan Politeknik Kesehatan Kemenkes Malang dengan Reg.No:023/KEPK-POLKESMA. Data diambil menggunakan instrumen penelitian berupa pedoman wawancara dan kuesioner, dan dilakukan pengolahan menggunakan uji Spearman.

\section{Hasil dan Pembahasan}

Penelitian dilakukan dengan melibatkan sampel terpilih dari Fakultas Ilmu Keolahragaan, analisis menunjukkan hubungan antara faktor pengetahuan dan faktor sikap terhadap kejadian keputihan selama tiga bulan terakhir.

\subsection{Karakteristik Responden Berdasarkan Jurusan}

Tabel 1. Karakteristik Mahasiswa Berdasarkan Jurusan

\begin{tabular}{lcc}
\hline \multicolumn{1}{c}{ Jurusan } & Frekuensi (n) & Presentase (\%) \\
\hline Pendidikan Jasmani Kesehatan dan Rekreasi (PJKR) & 33 & $25 \%$ \\
Pendidikan Kepelatihan Olahraga (PKO) & 18 & $13 \%$ \\
Ilmu Keolahragaan (IK) & 10 & $8 \%$ \\
Ilmu Kesehatan Masyarakat (IKM) & 73 & $54 \%$ \\
Total & 134 & $100 \%$ \\
\hline
\end{tabular}

Berdasarkan tabel di atas menunjukkan bahwa karakteristik jurusan di Fakultas Ilmu Keolahragaan angkatan 2019 sebagian besar ada pada jurusan Ilmu Kesehatan Masyarakat sejumlah 73 responden (54\%) sesuai dengan yang dirancang oleh peneliti.

\subsection{Hasil Kuesioner Kejadian Keputihan pada Mahasiswi Fakultas Ilmu Keolahragaan (FIK) angkatan 2019}

Tabel 2. Kejadian Keputihan

\begin{tabular}{lcc}
\hline & Frekuensi & Presentase (\%) \\
\hline Ya & 111 & 82,8 \\
Tidak & 23 & 17.2 \\
Total & 134 & 100 \\
\hline
\end{tabular}


Data responden yang digunakan dalam penelitian ini berjumlah 134 orang. Berdasarkan tabel diatas diperoleh bahwa mahasiswi FIK angkatan 2019 lebih banyak mengalami kejadian keputihan dibandingkan dengan tidak mengalami keputihan. Sebanyak 111 orang $(82,8 \%)$ mengalami kejadian keputihan, untuk yang tidak mengalami keputihan sebanyak 23 orang $(17,2 \%)$.

\subsection{Hasil Kuesioner Pengetahuan pada Mahasiswi Fakultas Ilmu Keolahragaan (FIK) angkatan 2019}

Tabel 3. Pengetahuan

\begin{tabular}{lcc}
\hline & Frekuensi & Presentase (\%) \\
\hline Tinggi & 132 & 98.5 \\
Rendah & 2 & 1.5 \\
Total & 134 & 100 \\
\hline
\end{tabular}

Dari 132 responden didapatkan data dengan mayoritas memiliki kategori pengetahuan tinggi dengan jumlah 132 orang (98,5\%) sedangkan kategori pengetahuan rendah sebanyak 2 orang $(1,5 \%)$.

\subsection{Hasil Kuesioner Sikap pada Mahasiswi Fakultas Ilmu Keolahragaan (FIK) angkatan 2019}

Tabel 4. Perilaku Hygiene Perorangan

\begin{tabular}{lcc}
\hline & Frekuensi & Presentase (\%) \\
\hline Baik & 133 & 99.3 \\
Buruk & 1 & 0.7 \\
Total & 134 & 100 \\
\hline
\end{tabular}

Tabel 4. diatas diperoleh bahwa mahasiswi FIK angkatan 2019 lebih banyak memiliki kategori sikap baik dibandingkan dengan kategori sikap buruk. Kategori sikap baik yaitu sebanyak 133 orang $(99,3 \%)$ sedangkan kategori sikap buruk yaitu sebanyak 1 orang $(0,7 \%)$.

\subsection{Hasil Analisis Bivariat Hubungan antara Pengetahuan dengan Kejadian Keputihan}

Tabel 5. Hubungan antara Pengetahuan dengan Kejadian Keputihan

\begin{tabular}{llcc}
\hline & & Kejadian Keputihan & Pengetahuan \\
\hline Kejadian & Pearson Correlation & 1 & -0.056 \\
Keputihan & Sig. (2-tailed) & & 0.520 \\
& N & 134 & 134 \\
Pengetahuan & Pearson Correlation & -0.056 & 1 \\
& Sig. (2-tailed) & 0.520 & 134 \\
& N & 134 & \\
\hline
\end{tabular}

Berdasarkan hasil uji diatas, diperoleh nilai koefisien korelasi sebesar -0,056 berarti $\mathrm{r}$ hitung $<r$ tabel $(0,159)$ artinya hubungan negatif dan tingkat hubungan yang sangat rendah 
antara pengetahuan dengan kejadian keputihan. Selanjutnya pengujian menggunakan nilai $\mathrm{p}$ value sebesar 0,520 , dimana nilai $\mathrm{p}=0,520>0,05$ yang menunjukkan bahwa tidak terdapat hubungan yang signifikan antara pengetahuan dengan kejadian keputihan pada mahasiswi FIK angkatan 2019. Pada hasil uji analisis statistik bivariat antara pengetahuan dan kejadian keputihan pada tabel 5 menghasilkan nilai signifikan ( $p$ value) sebesar 0,520 sehingga terdapat nilai yang lebih besar dari 0,05 ( $p>0,05)$. Hal tersebut mengartikan bahwa tidak ada hubungan yang signifikan antara pengetahuan dengan kejadian keputihan pada mahasiswi Fakultas Ilmu Keolahragaan (FIK) angkatan 2019 Universitas Negeri Malang. Hubungan signifikan antara dua hal tersebut tergolong rendah, artinya tingkat pengetahuan hanya berhubungan rendah dengan kejadian keputihan yang dialami mahasiswi.

Adapun penelitian serupa yang berjudul "Hubungan Antara Pengetahuan dan Sikap Remaja dengan Kejadian Fluor Albus Remaja Putri SMKF X Kediri” yang dilakukan dengan pendekatan cross-sectional dengan total sampling sejumlah 105 responden, menggunakan instrumen berupa kuesioner kemudian dianalisis menggunakan uji spearman rho. Hasilnya diketahui tidak adanya hubungan antara pengetahuan dengan fluor albus yaitu p > 0,05 (Sari, 2016). Artinya pada penelitian Sari (2016) menghasilkan kesimpulan pengetahuan tidak ada hubungan dengan kejadian fluor albus. Penelitian lainnya juga menyampaikan hal yang sama, ada pada judul "Hubungan Antara Pengetahuan dan Perilaku Remaja Putri dalam Menjaga Kebersihan Alat Genitalia dengan Kejadian Keputihan di SMA Negeri 2 Pineleng” yang menggunakan cross sectional dengan total sampling sebanyak 60 orang, data didapatkan dari pengisian kuesioner. Selanjutnya dianalisis menggunakan Chi-square test dengan hasil $p$ value sebesar 0,628 > 0,05. Artinya, hubungan pengetahuan dan keputihan tidak ada (Nanlessy, 2013). Adapun perbedaan yang didapat oleh peneliti yaitu responden yang didapatkan adalah mahasiswi yang berpengetahuan baik namun juga mengalami keputihan. Sedangkan pada responden penelitian Nanlessy tidak memiliki pengetahuan yang baik karena beberapa faktor antara lain tidak pernah mendapatkan penyuluhan tentang topik terkait dan alat-alat teknologi yang kurang memadai. Hal tersebut diakui menjadi alasan responden kurang mampu mencegah untuk tidak mengalami keputihan.

Kesimpulan yang dapat diambil dari beberapa penelitian diatas yaitu terdapat perbedaan penelitian yang dilakukan oleh peneliti dengan peneliti lainnya. Bentuk perbedaannya antara lain metode pengambilan data, metode pengambilan sampel, jumlah sampel, instrumen, serta analisis data yang digunakan. Hal ini memungkinkan untuk memunculkan hasil penelitian yang tidak signifikan atau tidak berhubungan. Perbedaan yang disebutkan diatas terjadi karena adanya keadaan yang perlu disesuaikan dengan kondisi, keperluan dan tujuan penelitian. Notoatmodjo (2012) menyampaikan bahwa pengetahuan dalam domain kognitif terdapat beberapa tingkatan yaitu tahu diartikan setelah mengamati sesuatu, lalu selanjutnya adalah memahami dan mengaplikasikan. Namun pada penelitian ini tingkat pengetahuan responden termasuk baik tetapi juga dominan mengalami keputihan. Hal tersebut kemungkinan terjadi karena seseorang belum memahami dan mengaplikasikan hal yang diketahui tentang keputihan. 
Sport Science and Health, 3(9), 2021, 663-669

\subsection{Hasil Analisis Bivariat Hubungan antara Sikap dengan Kejadian Keputihan}

Tabel 6. Hubungan antara Sikap dengan Kejadian Keputihan

\begin{tabular}{llcc}
\hline & & Kejadian Keputihan & Sikap \\
\hline Kejadian & Pearson Correlation & 1 & -0.039 \\
Keputihan & Sig. (2-tailed) & & 0.651 \\
& N & 134 & 134 \\
Sikap & Pearson Correlation & -0.039 & 1 \\
& Sig. (2-tailed) & 0.651 & \\
& N & 134 & 134 \\
\hline
\end{tabular}

Berdasarkan hasil uji statistik pada tabel 6, diperoleh nilai koefisien korelasi sebesar 0,039 yang artinya terdapat hubungan negatif dan tingkat hubungan yang sangat rendah antara variabel yang dianalisis. Setelah dilakukan uji koefisien korelasi p value yaitu sebesar 0,651 dimana nilai $\mathrm{p}=0,651>0,05$ yang menunjukkan bahwa tidak terdapat hubungan atau korelasi yang signifikan antara sikap dengan kejadian keputihan pada mahasiswi FIK angkatan 2019. Hal tersebut disimpulkan bahwa hubungan antara perilaku higiene perorangan dengan kejadian keputihan tidak ada. Dilihat dari tidak adanya hubungan antara dua variabel tersebut menandakan bahwa keeratan yang rendah dan menjadikan adanya kemungkinan faktor lain yang berhubungan kuat dengan kejadian keputihan selain perilaku higiene perorangan pada sampel yang ditentukan. Hubungan yang tidak ada antara variabel tersebut diatas juga didapatkan dari hasil penelitian Darma (2017), dengan sampel sebanyak 81 orang yang didapatkan dari teknik proportional stratified random sampling. Data yang diambil dengan pendekatan cross sectional diuji statistik menggunakan chi-square ( $p$-value $=0,491)$. Penelitian lain yang juga sejalan ialah penelitian yang dilakukan oleh Nurhayati (2013), disebutkan tidak ada hubungan karena nilai $p$ value dari hasil uji chi-square pada 130 sampel sebesar 0,806 $>0,05$.

Pada kuesioner penelitian ini sebesar 50\% responden menjawab "Ya" pada pernyataan pengetahuan bahwa celana yang lembab dan tidak segera diganti tidak akan menyebabkan keputihan. Selain itu pendapat mayoritas responden pada kuesioner sikap menyatakan sangat setuju dengan perilaku penggunaan celana dalam lembab menjadi penyebab keputihan. Namun ternyata dengan kondisi tersebut sebanyak 54,6\% mengalami keputihan akibat menggunakan celana yang tidak menyerap keringat dan ketat. Komponen sikap yang ada pada hasil peneliti tidak sampai pada tingkat bertanggung jawab karena pada tingkat responding tidak dilakukan secara maksimal. Seperti halnya pada penelitian ini, responden memiliki pendapat perilaku yang baik $(\mathrm{N}=133)$ namun tetap mengalami keputihan karena ada beberapa hal yaitu, paham dan berpendapat sesuai teori namun tidak mempraktekkannya dan atau mempraktekannya namun tidak menerima sepenuhnya dan tidak konsisten.

Meskipun hasil yang didapatkan oleh penelitian sama atau $\mathrm{p}$ value $>0,05$ ada hal yang perlu diperhatikan bahwa metode pengambilan sampel, jumlah sampel, instrumen, serta analisis data berbeda. Hal tersebut dikarenakan keperluan dan kondisi peneliti perlu disesuaikan dengan tujuan. Sikap bukan merupakan satu-satunya penyebab kejadian keputihan namun ada beberapa lainnya, seperti riwayat penyakit, demografi (status ekonomi, usia, dst). Faktor pendorongnya seperti lingkungan, keluarga serta faktor paling utama yaitu pengetahuan, sikap dan perilaku higiene perorangan. Jadi perlu adanya penelitian serupa dengan faktor lainnya agar menemukan hasil yang signifikan pada sampel yang sama. 


\section{Simpulan}

Berdasarkan hasil penelitian yang dilakukan, maka diperoleh kesimpulan yaitu: Tidak ada hubungan yang signifikan antara pengetahuan dan kejadian keputihan pada mahasiswi Fakultas Ilmu Keolahragaan Angkatan 2019 Universitas Negeri Malang. Tidak ada hubungan yang signifikan antara sikap dan kejadian keputihan pada mahasiswi Fakultas Ilmu Keolahragaan Angkatan 2019 Universitas Negeri Malang.

\section{Daftar Rujukan}

Abiyoga. (2019). Hubungan Antara Gangguan Pola Tidur Dengan Flour Albus (Keputihan) Pada Remaja. Jurnal Medika : Karya Ilmiah Kesehatan, 3(2), 1-10. https://doi.org/10.35728/jmkik.v3i2.41

Darma. (2017). Hubungan Pengetahuan, Vulva Hygiene, Stres, Dan Pola Makan Dengan Kejadian Infeksi Flour Albus (Keputihan) Pada Remaja Siswi Sma Negeri 6 Kendari 2017. Jurnal Ilmiah Mahasiswa Kesehatan Masyarakat Unsyiah, 2(6), 198314.

Febryary. (2016). Gambaran Pengetahuan, Sikap Dan Perilaku Remaja Putri Dalam Penanganan Keputihan Di Desa Cilayung. Jurnal Sistem Kesehatan, 2(1), 40-46. https://doi.org/10.24198/jsk.v2i1.10418

Ilmiwati \& Kuntoro. (2017). Pengetahuan Personal Hygiene Remaja Putri pada Kasus Keputihan. Jurnal Biometrika Dan Kependudukan, 5(1), 43. https://doi.org/10.20473/jbk.v5i1.2016.43-51

Irmayanti \& Lusiana. (2017). Hubungan Vulva Hygiene Dan Penggunaan Akdr Dengan Kejadian Keputihan Pada Wanita Usia Subur Di Wilayah Kerja Puskesmas Paal Merah I Kota Jambi Tahun 2016. 6(01), 7-13.

Lazenby. (2013). Correlation of leukorrhea and Trichomonas vaginalis infection. Journal of Clinical Microbiology, 51(7), 2323-2327. https://doi.org/10.1128/JCM.00416-13

Nanlessy. (2013). Hubungan Antara Pengetahuan Dan Perilaku Remaja Puteri Dalam Menjaga Kebersihan Alat Genitalia Dengan Kejadian Keputihan Di Sma Negeri 2 Pineleng. Jurnal Keperawatan UNSRAT, 1(1), 106359.

Nikmah \& Widyasih. (2018). Personal Hygiene Habits dan Kejadian Flour Albus Patologis pada Santriwati PP AL-Munawwir, Yogyakarta. Media Kesehatan Masyarakat Indonesia, 14(1), 36. https://doi.org/10.30597/mkmi.v14i1.3714

Notoatmodjo. (2012). Promosi Kesehatan dan Perilaku Kesehatan.

Sari. (2013). Identifikasi Faktor Penyebab Keputihan Pada Remaja Putri. Journal of Chemical Information and Modeling, 53(9), 1689-1699. https://doi.org/10.1017/CB09781107415324.004

Sari, P. M. (2016). Hubungan Antara Pengetahuan Dan Sikap Remaja Dengan Kejadian Fluor Albus Remaja Putri Smkf X Kediri. Hubungan Antara Pengetahuan Dan Sikap Remaja Dengan Kejadian Fluor Albus Remaja Putri SmkfX Kediri, Vol. 3(No. 1), 1-4.

Sugiyono. (2018). Metode Penelitian Kuantitatif. Alfabeta.

Wati. (2017). Hubungan Tingkat Pengetahuan dengan Cara Pencegahan Flour Albus Di SMK Ahmad Yani Gurah Kediri. Journal of Chemical Information and Modeling, 53(9), 1689-1699. https://doi.org/10.1017/CB09781107415324.004 